\title{
上顎全摘術における眼窩底と口蓋骨の再建
}

\author{
門倉 義幸122) ・宔田 哲昭2) ・ 松井 和夫22 \\ 竹村 栄毅2) ・ 柳 祐一郎1) - 角谷 徳芳3

\section{Reconstruction of the Orbital Floor and Palate after Total Maxillectomy}

\author{
Yoshiyuki Kadokura and Yuichiro Yanagi \\ (Showa University Yokohama Northern Hospital) \\ Tetsuaki Kubota, Kazuo Matsui, Hideki Takemura and Yoshinori Sumiya \\ (Showa University Fujigaoka Hospital)

\begin{abstract}
After total maxillectomy patients sometimes develop diplopia and difficulty in swallowing. In this study we tried using an osteocutaneous flap with a lattisimus dorsi flap and a collagen plate to reconstruct the maxilla. We thought that using this method would be useful after a total maxillectomy.
\end{abstract}

Key words : total maxillectomy, reconstruction of the orbital floor, scapular flap, lattisimus dorsi flap

はじめに

上顎全摘後の問題点として，眼窩内容沈下による複視 と口蓋骨欠損による摂食構音障害が挙げられる. 今回, われわれは上顎全摘後の再建に際し肩甲下動静脈からの 一対の血管柄によって 2 つ皮弁，すなわち広背筋皮弁 と肩甲骨を含んだ肩甲皮弁とわれわれの開発したコラー ゲンプレート1)を同時使用することにより良好な結果を 得たので報告する.

\section{症例}

症例 : 58 歳, 男性.

主訴: 右煩部痛.

現病歴: 平成 6 年 10 月頃より鼻閉塞感を自覚するも放 置していた. その後鼻出血, 右㚘部痛が出現したため平 成 7 年 1 月 7 日近医耳鼻科受診, 右上效腫愓を指摘され, 精查加療目的にて 1 月 10 日当院紹介受診となった.

家族歴：特記すべきことなし。
既往歷：陳旧性肺結核.

趣向：たばこ 30 本 $\times 30$ 年.

初診時所見: 患者の顔貌は, 著明な右煩部腫脹をきた

し右鼻腔内の腫崵によって鼻中隔とともに鼻背部が左側

へ変位していた. また, 鼻腔内の腫瘍は前鼻孔まで突出 し, 右眼球の軽度上方偏位を認めたが, 眼球運動障害, 複視は認められなかった。

検查: CT にて右上顎腫揚は, 眼窩底, 上顎洞後壁, 硬 口蓋に浸潤を認め (図 1), 上顎癌 T3N0M0 の診断のも と 1 月 30 日入院, ただちに放射線療法 $40 \mathrm{~Gy}$ と化学療法 2 クール施行したが, 腫瘍縮小効果にそしく 3 月 14 日全 身麻酔下に手術を施行した。

手術は, 右根治的頸部郭清術および右上顎全摘出術を 行い, 上顎摘出では鼻側切開線の皮切を用い, 広く上顎 骨を露出した上, 腫瘍浸潤を認めた眼窩底と硬口蓋を広 く切除した（図 2). まず上方の再建を行った. 眼窩の下 壁骨および内側壁が広く切除され, 同時に眼球被膜, 脂

\footnotetext{
1）昭和大学横浜市北部病院耳鼻咽喉科

2) 昭和大学藤が丘病院耳鼻咽喉科

3）昭和大学藤が丘病院形成外科
} 


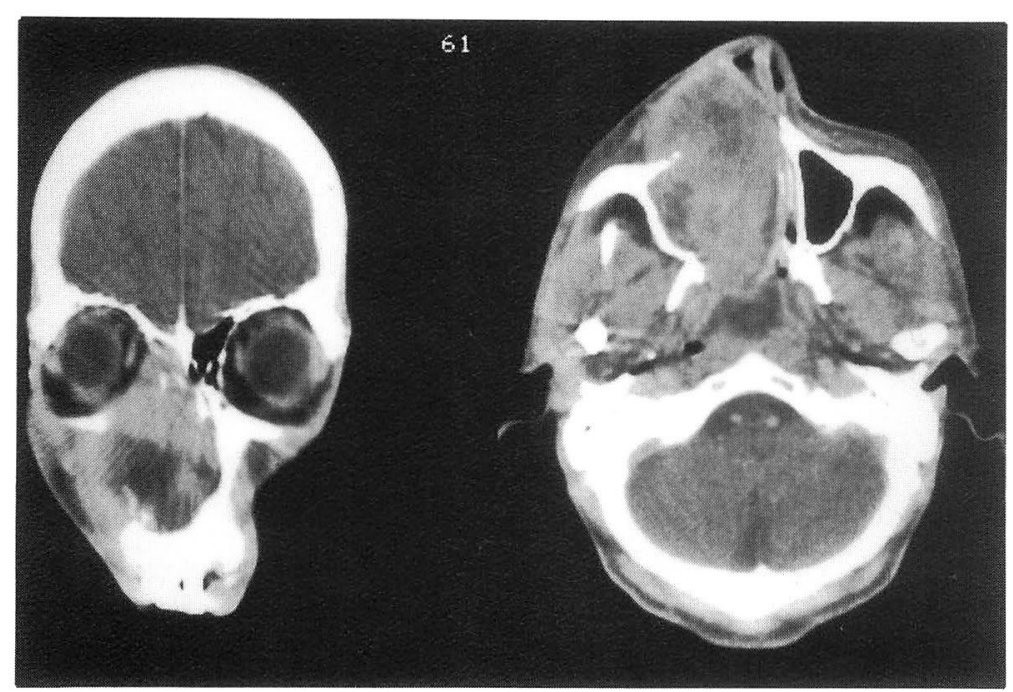

図 1 術前 CT
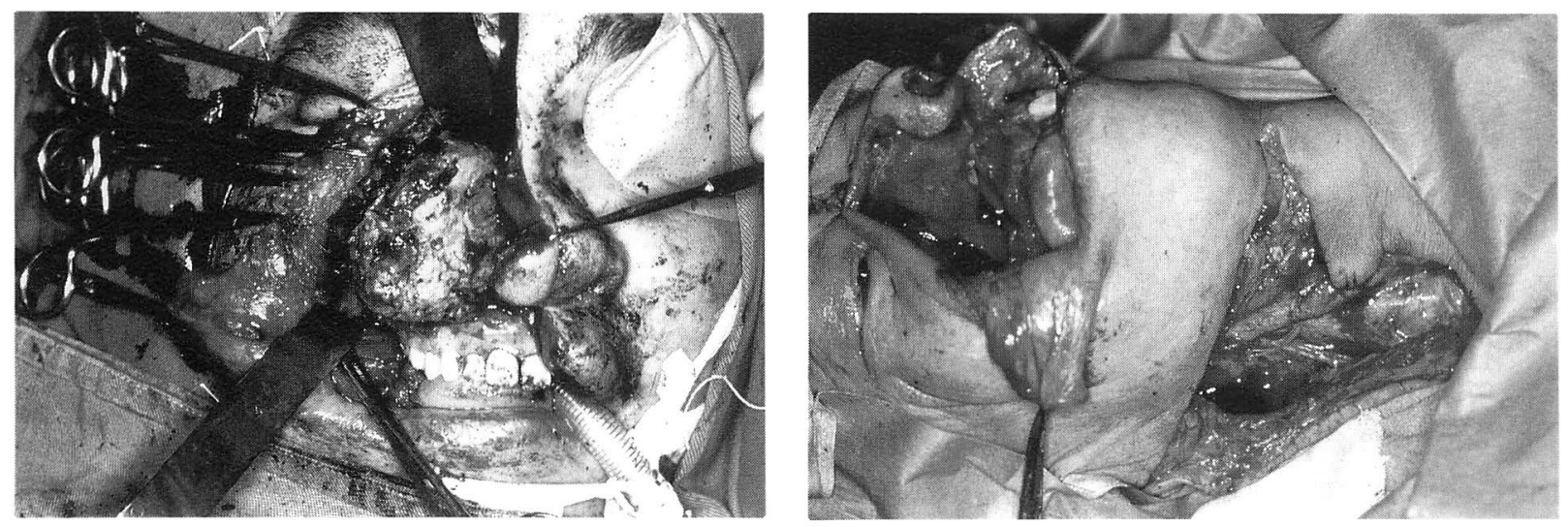

図 2 術中所見

腫瘍浸潤のため眼窝底と硬口盍を合併切除。

肪織の一部も切除されて, 眼窩内脂肪織が露出している ためこれを被い，さらに眼窩内容沈下を防止するためコ ラーゲンプレートを使用した。 これはわれわれが人工気 管として開発したコラーゲンプレートと同質のもので, 適度な軟骨様硬度を保ちつつ約 2 力月で結合織と置換す る.図 3 のごとく, 眼窩内容を下方よりコラーゲンプレー トにて被覆し, その後, 縁を眼窩先端部残存骨壁にはさ み,フィブリン接着剤で固定, 眼位を正常の高さに保つ ことを考慮しながらその前縁を下眼瞼筋層に縫合固定し た. 続いて口蓋欠損部の再建を行った. 皮弁は図 4 のご とく，広背筋皮弁と肩甲骨を含んだ肩甲皮弁をデザイン した. 両者の栄養血管は, 広背筋は胸背動静脈で, 肩甲
皮弁は肩甲回旋動静脈であるが，両者は肩甲下動静脈か ら分岐されているため，この血管を顔面動脈および外頸 静脈にそれぞれ吻合した．採取した皮弁のうち，肩甲骨 は栄養血管を損傷しないように切れ目を入れ，L 字型に 細工し，チタンプレートにて形を保持し，その両端を煩 骨体部と残存口蓋骨端にそれぞれ同様のプレートで固定 することで上顎の骨枠を作成した。この骨組みに付随し た肩甲皮弁の中央部の皮膚を denude することで二分し， 骨成分のない部分を鼻腔側壁の再建に使用し，骨を含む 範囲を口蓋に使用することとし，鼻腔側および口蓋口腔 側に皮膚面がくるようにそれぞれ周囲残存粘膜と縫合し 再建した. 次いで, 先に眼窩底に敷いたコラーグンプレー 


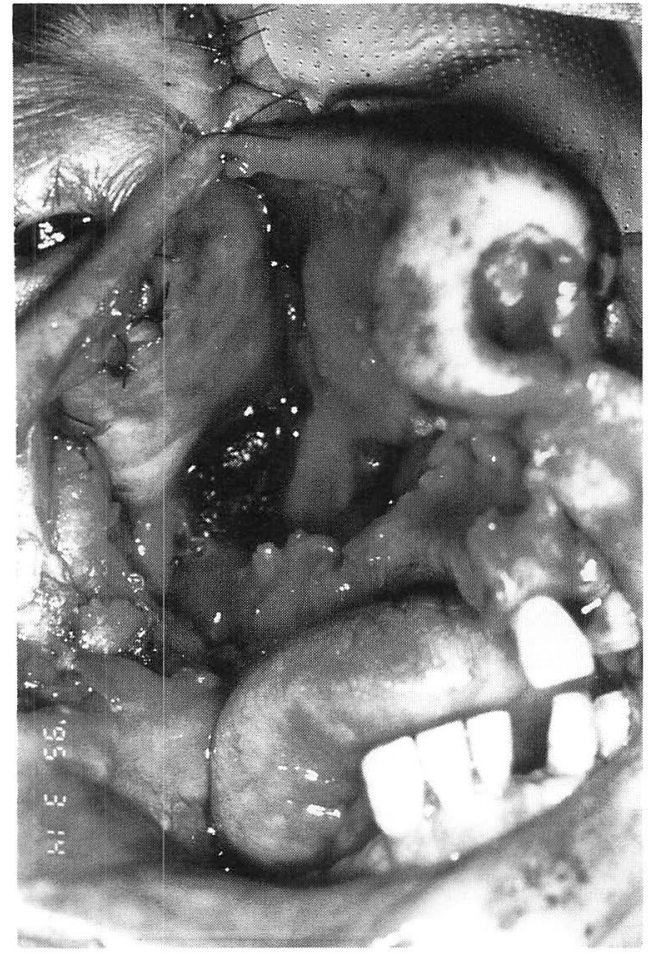

図 3 コラーゲンプレートによる眼窩底再建

卜を支えるように広背筋筋弁を上顎スペースに充填する ことによって眼窩内容物の沈下を防止した（図 5)。その 際, 皮䖉は不必要となったため, 筋弁のみの充填を行っ た. 図 6 に再建シェーマを示した. 図 7 に現在の顔貌と CT 像を示す. 外鼻は術前の変位のままであるが, 眼位は

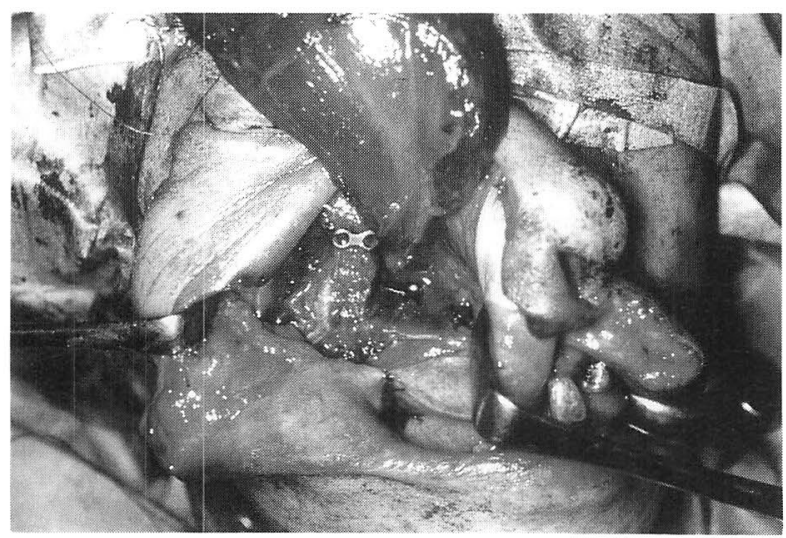

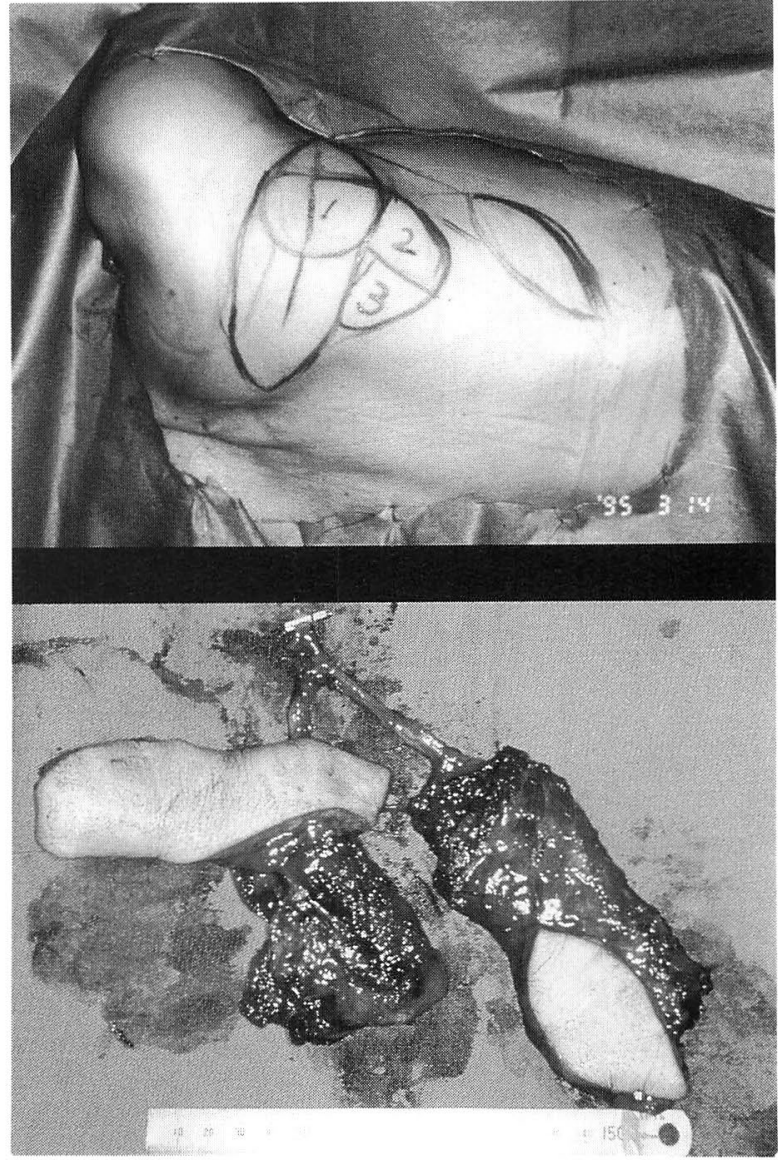

図 4 採取された肩甲皮弁

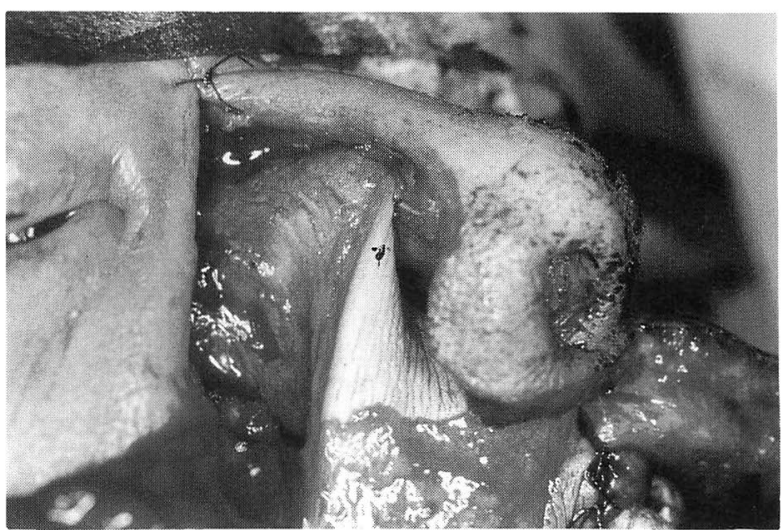

b

図 5 上顎の再建

（a）肩甲骨をL字型に形成し上顎骨枠を作成.

(b) 広背筋筋弁で上顎スペースを充填. 


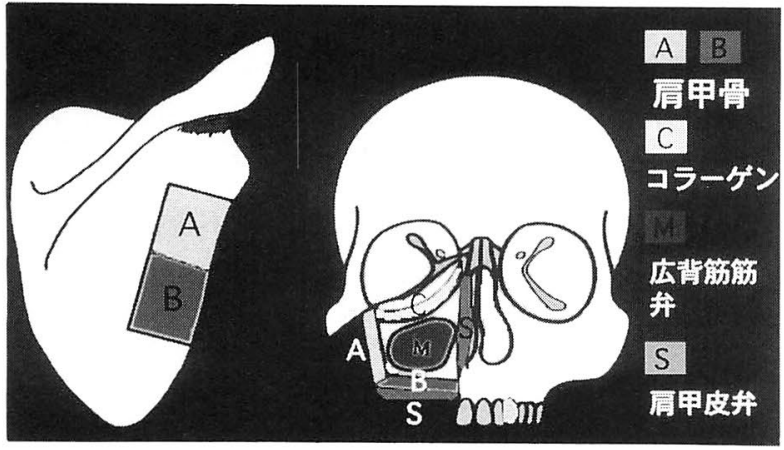

図 6 肩甲骨骨採取部位と再建方法のシェーマ

良好に保たれている. 図 8 に口腔内の再建部を示す。現 在片側の歯で咀嚼を行っているが，摂食は通常に行われ ており構音障害もない. 腫瘍に関しては術後照射 $20 \mathrm{~Gy}$ を追加し，7 年を経た現在再発の兆候はない.

\section{考 察}

肩甲皮弁は，採取時に側臥位としなければならないと いう欠点はあるが肩甲下動脈を血管茎とする皮弁は血管 茎も太く皮虚, 筋肉, 骨と皮弁としての応用範囲は広い。 特に肩甲骨は，肩甲回旋動脈から肩甲骨外側縁を栄養す る骨枝と胸背動脈からの肩甲骨下角の栄養枝である角枝 によって二重に支配されるため, 血管柄付きで骨切りが 容易かつ安全に行うことが可能である。こうした利点か ら上顎，下顎再建など骨性支持が必須の場合の適応とし
て都合がよい，上顎再建には，広背筋皮弁，腹直筋皮弁， 肩甲皮弁などが主に用いられているが，肩甲皮弁に関し ては, Coleman ら ${ }^{2)}$ が提唱するように，肩甲下動脈で栄 養される領域を一括して考えることによって多種類の遊 離組織移植が可能であり, 最近では肩甲下動静脈系複合 皮弁として症例に応じた複合皮弁が挙上される傾向にあ り，金子ら ${ }^{3)}$ は，上顎，下顎再建 22 症例を報告し良好な 成績をおさめている。

一方, 眼窩底の再建に使用したコラーゲンプレート(図 9）による再建は，1980 年より当教室において行われて おり，牛の皮膚由来のハイドコラーゲンで HMDIC (hexamethylendiisocianate) で架橋を入れることにより強 度ある吸収されにくい材質に計画されており1)，われわ れが従来より上方進展型上顎癌において眼窩底骨を広く 切除した場合の眼窩底の再建や甲状腺癌の広範囲気管浸 潤症例に対する気管再建材料に使用している4) 6).

またコラーゲン板による眼窩底再建では，上顎部にバ ルーンを留置しておくことにより術後に眼位を正しく修 正することも可能となる. 通常眼球の下方からの固定は 広背筋筋弁だけでも十分であり，今回の皮弁では，広背 筋筋体を上顎部に充填したので必ずしもコラーゲンプ レートを使用しないで凮むが，これを使用することで露 出した眼窩内容をまとめ眼位をできるだけ正常に近く保 持するために有効と考えている.

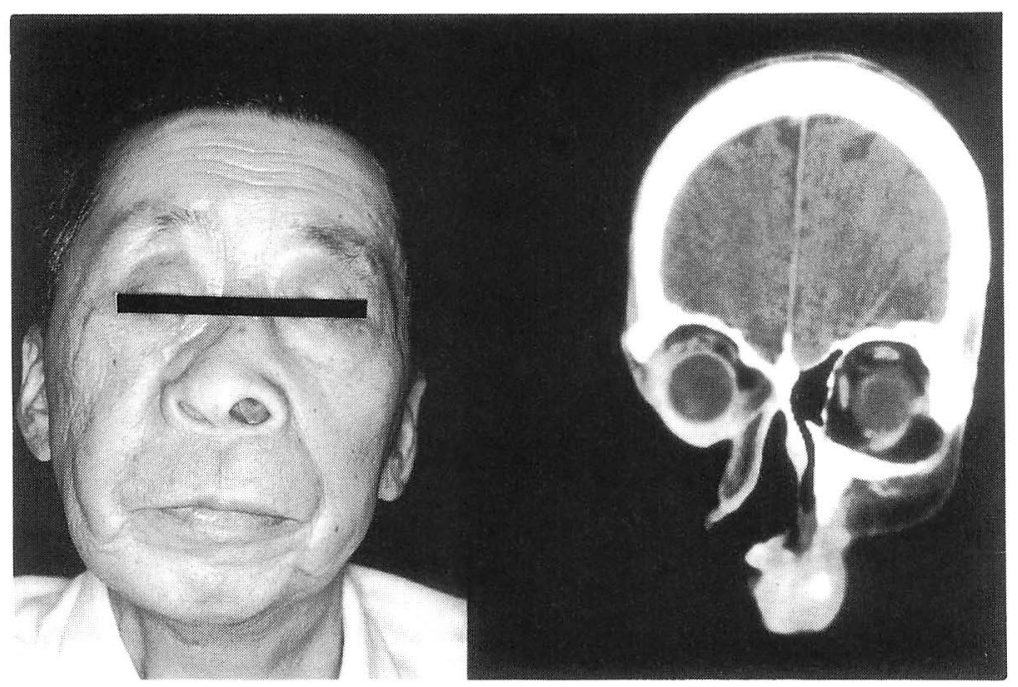

図 7 術後の顔貌と CT 像 


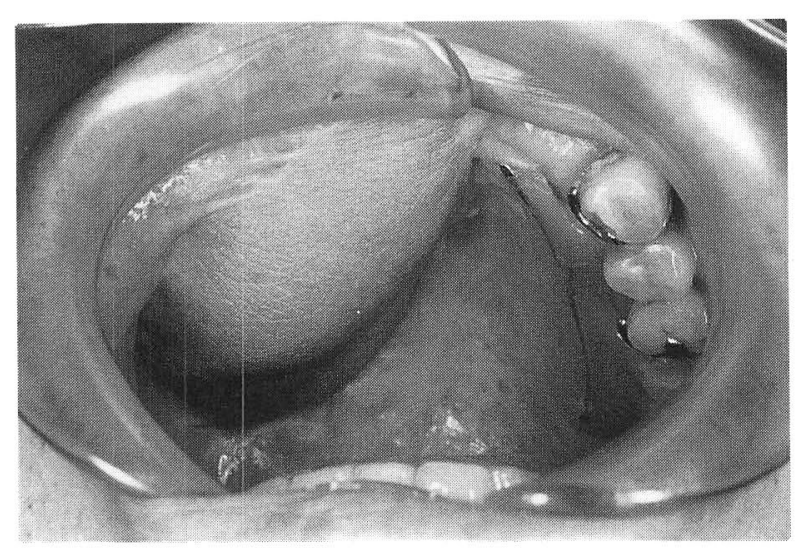

図 8 術後口腔内所見

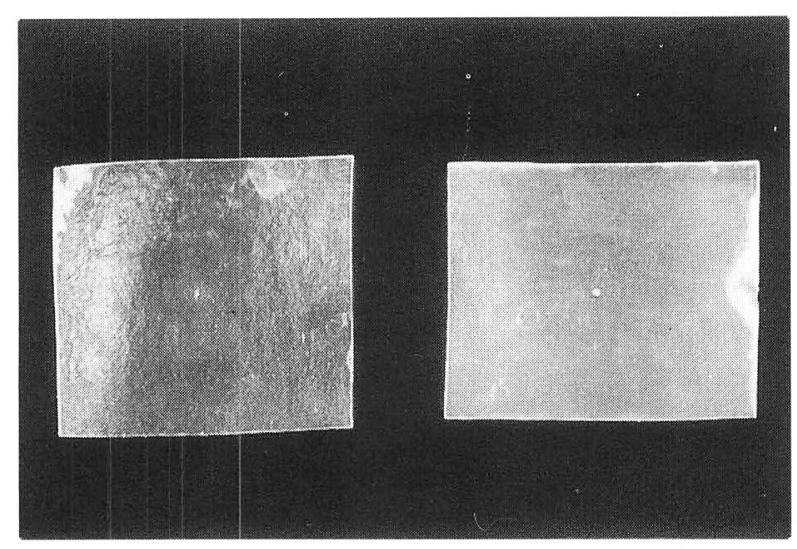

図 9 コラーゲンプレート
まとめ

1）上顎全摘後に広背筋皮弁と肩甲骨を含んだ肩甲皮弁 とわれわれの開発したコラーゲンプレートを同時使用し た上顎再建術式を報告した。

2)眼窩底の再建ではコラーゲンプレートを使用するこ とで眼位をほぼ正常に保持することが可能であった。

本論文の要旨は第 20 回日本頭頸部腫瘍学会（平成 8 年 7 月, 福井市) において報告した。

\section{参考文献}

1）門倉義幸：コラーグン人工気管による気道再建に関する基 礎的研究. 昭和医会誌 $61: 458 \sim 467,2001$.

2) Coleman JJ 3rd and Sultan MR : The bipedicled osteocutaneous scapula flap; a new subscapular system free flap. Plast Reconstr Surg 87 : 682 692, 1991.

3）金子 凮，中嶋英雄，藤野豊美：肩甲下動脈系複合皮弁を 用いた上顎・下顎再建. 頭頸部腫瘍 $20: 446 \sim 452,1994$.

4）門倉義幸, 窪田哲昭, 大谷尚志, 他：甲状腺乳頭癌気管浸 潤症例に対する治療法の検討. 頭頸部腫瘍 22 : $106 \sim 111$, 1996.

5）窪田哲昭:気管内へ侵入した頸部神経線維腫の1例とコラー ゲン膜による気管再建の試み. 日気食会報 $36: 317 \sim 322$, 1985.

6）洼田哲昭：甲状腺乳頭癌気管浸潤の取り扱い. JOHNS 9 : $1783 \sim 1788,1993$.

別刷請求先：門倉義幸

干224-0032 横浜市都筑区茅ヶ崎中央 $35-1$

昭和大学横浜市北部病院耳鼻咽喉科 